\title{
New Monoclonal Antibodies Directed Against Human Renin \\ Powerful Tools for the Investigation \\ of the Renin System
}

F. X. Galen, C. Devaux, S. Atlas, T. Guyenne,

J. Menard, and P. Corvol

Institut National de la Santé et de la Recherche Médicale, U36, 75005 Paris, France

D. Simon, C. Cazaubon, P. Richer, G. Badouaille, J. P. Richaud, P. Gros, and B. Pau

Centre de Recherches, Clin-Midy-Montpellier, France

A against human renin were obtained by the fusing of myeloma cells with spleen cells from Balb/c or highresponder Biozzi mice injected with pure tumoral or highly purified renal renin. These procedures resulted in the production of seven stable monoclonal antibodies to human renin. Antibodies in the hybridoma culture medium were screened by binding to pure iodinated renin or insolubilized renin in a solid phase assay. The concentration of purified antibodies that provided a $50 \%$ binding to iodinated renin varied from $1 \times 10^{-10}$ to $1 \times 10^{-7} \mathrm{M}$. Two monoclonal antibodies were found to be potent inhibitors of renin enzymatic activity in vitro, behaving as noncompetitive inhibitors $(\mathrm{Ki}, 1$ to 4 $\left.\times 10^{-10} \mathrm{M}\right)$. They were specific for primate renin. Three monoclonal antibodies provided suitable immunoadsorbants for renin purification. One of these immunoadsorbants was used for large-scale purification of the renal enzyme, resulting in an 825-fold renin enrichment in a single step. Two antibodies were able to distinguish between active and inactive renin and enabled concomitant separation and purification of the two enzyme forms in various biological fluids. Monoclonal antibodies also stained human and monkey renal renin when indirect immunofluorescence and peroxidase-antiperoxidase techniques were used. A highly sensitive radioim-

Dr. Atlas is with the Hypertension Center, New York Hospital-Cornell Medical Center, New York.

Received for publication 11 August 1983 and in revised form 10 May 1984.

J. Clin. Invest.

(c) The American Society for Clinical Investigation, Inc.

0021-9738/84/09/0723/13 \$1.00

Volume 74, September 1984, 723-735 munometric assay of renin was constructed with two monoclonal antibodies. The sensitivity of this improved assay should permit the detection of renin in normal human plasma. Monoclonal antibodies have been shown to be superior to polyclonal antibodies in the following areas: the separation of active from inactive renin, the purification of renin from biological fluids, and the setting up of a direct assay of plasma renin.

\section{Introduction}

Renin (EC 3-4-99-19), a key enzyme in the regulation of blood pressure and sodium and potassium metabolism, is present in human kidney and biological fluids in minute quantities. Its purification from a juxtaglomerular cell tumor (1) and from cadaver kidney $(2,3)$ facilitated the characterization of the enzyme and the generation of polyclonal antibodies in the rabbit. Polyclonal antibodies against human renin were used to set up a direct radioimmunoassay (RIA) ${ }^{1}$ (4), to localize renin by immunohistochemistry $(5,6)$, and to block in vivo the renin enzymatic activity in an experimental model of hypertension in the monkey $(7,8)$. There are, however, several limitations in the use of antirenin polyclonal antibodies: The scarcity of pure human renin means that the supply of antisera is limited and that the purification of antibodies on a renin affinity column is not feasible. These antibodies cannot distinguish between active and inactive plasma renin $(9,10)$. Inactive renin can be fully activated by limited proteolysis, acidification, or cold exposure (see review, 11). The exact nature of inactive renin has not been elucidated, but the availability of antibodies that could distinguish between these two forms would be extremely valuable.

For these reasons, monoclonal antibodies directed against human renin were sought. The preparation of such a mono-

1. Abbreviations used in this paper: GU, Goldblatt unit; MRC, Medical Research Council (Holly Hill, London); PAP, peroxidase-antiperoxidase; PRA, plasma renin activity; RIA, radioimmunoassay. 
clonal antibody, F15, has recently been reported (12). This antibody had a low affinity for renin, poorly inhibited renin enzymatic activity, could not distinguish between active and inactive renin, and could not be used for renin immunohistochemistry; however, it enabled effective purification of renin by immunoaffinity. This paper describes the search for a set of monoclonal antibodies against human renin that would overcome the limitations of the currently available polyclonal and monoclonal antibodies.

The strategy used was to purify human kidney renin by immunoaffinity on a column of F15-Sepharose gel. This purified renin, along with pure renin obtained in this laboratory (1), was injected into mice, and a set of monoclonal antibodies was obtained by lymphocyte hybridization. The following properties and applications of monoclonal antibodies were studied: their affinity, their specificity with regard to renin from different species and acid proteases, their ability to inhibit renin enzymatic activity, their usefulness in immunoaffinity chromatography, their ability to distinguish between active and inactive renin, their use for renin localization by immunohistochemistry, and the establishment of a new radioimmunometric assay of renin in human plasma. This study shows that monoclonal antibodies with different properties can be obtained and used for various investigations in the renin-angiotensin system.

\section{Methods}

\section{Human renin and polyclonal antibody sources}

I. INTERNATIONAL STANDARD RENIN. This kidney renin was donated by the Medical Research Council (MRC) (Holly Hill, London; lot 68/356).

II. CRUDE RENAL RENIN. Infarcted kidney removed at surgery was homogenized in $0.1 \mathrm{M}$ phosphate buffer, $\mathrm{pH} 7.5$, which contained protease inhibitors $(4 \mathrm{ml} / \mathrm{g}$ tissue) as described (13). After $30 \mathrm{~min}$ of centrifugation at $20,000 \mathrm{~g}$ the supernatant was removed and stored at $-20^{\circ} \mathrm{C}$. The specific activity was 0.5 Goldblatt units (GU)/mg protein

III. HAAS RENIN. This renin was partially purified from cadaver kidney (step V) (14) and was generously donated by Dr. Haas, Moun Sinai Hospital (Cleveland, $\mathrm{OH}$ ). The specific activity of the lyophilized preparation was $0.132 \mathrm{GU} / \mathrm{mg}$ protein.

IV. PURE RENIN. Pure renin was obtained from a juxtaglomerular cell tumor (1). The specific activity was $810 \mathrm{GU} / \mathrm{mg}$ protein. This preparation was used for the iodination of renin as described (4).

V. INACTIVE RENAL RENIN. Inactive renin was extracted from $480 \mathrm{~g}$ of human cadaver kidney cortex and was purified 290-fold (specific activity, $0.29 \mathrm{GU} / \mathrm{mg}$ protein, $52 \%$ recovery) on cibacron blue $F_{3} G A$ agarose (Bio-Rad Laboratories, Richmond, $C A$ ), phenylSepharose, and DEAE-Sepharose, as previously described (15). This was followed by immunoaffinity chromatography with the F15 monoclonal antibody coupled to Sepharose, performed as described below for active renin, except that the eluting buffer contained $0.04 \%$ bovine serum albumin (BSA) as carrier protein. The final specific activity was $5.8 \mathrm{GU} / \mathrm{mg}$, but $>98 \%$ of the contaminant was accounted for by BSA carrier. Inactive renin was measured by direct immunoassay with R 15 antibody, which recognizes to the same extent active and inactive renin. A calibration curve was built by the use of pure active renin, which allowed us to quantify inactive renin.
VI. INACTIVE CHORIONIC RENIN. This was renin released into the medium of cultured chorionic cells, as described by Acker et al. (16). It contained $3.32 \mathrm{mGU}$ of active renin and $78.9 \mathrm{mGU}$ of inactive renin per milliliter of medium.

VII. RENIN FROM AMNIOTIC LIQUID. Amniotic fluid was collected by amniocentesis during the third trimester of pregnancy. Amniotic liquid was centrifuged and stored at $-20^{\circ} \mathrm{C}$. It contained $1.09 \mathrm{mGU} / \mathrm{ml}$ of active renin and $9.4 \mathrm{mGU} / \mathrm{ml}$ of inactive renin.

VIII. PLASMA RENIN. $10 \mathrm{ml}$ blood was collected at $4^{\circ} \mathrm{C}$ on 100 IU dry heparin (Choay Lab., Paris), centrifuged, and stored at $-20^{\circ} \mathrm{C}$. Plasma was obtained from normal volunteers. For the separation of active and inactive renin on the 4G1-Sepharose column, plasma from a hypertensive patient with high renin activity was used (plasma renin activity (PRA), $39.6 \mathrm{ng}$ angiotensin $\mathrm{I} / \mathrm{ml}$ per $\mathrm{h}$ ).

IX. POLYCLONAL ANTIBODIES. Anti-human renin antibodies (referred to as R15) (4) inhibit renin enzymatic activity and stain renin in the human kidney (5).

\section{Production of renin monoclonal antibodies}

IMMUNIZATION. Balb/c or high-responder Biozzi mice (17) were injected with pure human renin purified from a juxtaglomerular cell tumor that had a specific activity of $810 \mathrm{GU} / \mathrm{mg}$ protein (1) or with renal human renin obtained by immunopurification (see below), specific activity $81 \mathrm{GU} / \mathrm{mg}$ protein. Different immunization protocols used in the five separate fusions are summarized in Table I. In all cases the first injection was given subcutaneously in complete Freund's adjuvant; the final injection was given either intravenously or intraperitoneally $3 \mathrm{~d}$ before the fusion. For the fusion experiment F29 the mouse received $5 \mu \mathrm{g}$ of renin intravenously. $4 \mathrm{~h}$ after the last injection, the splenocytes were isolated and the cells were cultured for $\mathbf{3} \mathrm{d}$ in a preconditioned medium (18) containing renin.

FUSION. Spleen cells were fused with the myeloma line by a method adapted from Di Pauli (19): Splenocytes and myeloma cells were washed and suspended in a serum-free medium (RPMI 1640). For each fusion, $10^{8}$ splenocytes and $2 \times 10^{7}$ myeloma cells were centrifuged together at $200 \mathrm{~g}$ for $10 \mathrm{~min}$ at room temperature. $1 \mathrm{ml} 40 \%$ polyethylene-glycol 1540 (Riedel-de Haën AG, Seelze, Hannover, West Germany) was added to the cell pellet dropwise over $30 \mathrm{~s}$ with gentle stirring. After $1 \mathrm{~min}$ at $37^{\circ} \mathrm{C}$ the cells were pelleted by centrifugation for $1.5 \mathrm{~min}$ at $300 \mathrm{~g}$ and incubated for another $2 \mathrm{~min}$ at $37^{\circ} \mathrm{C}$. The pellet was then diluted to $15 \mathrm{ml}$ by the addition of serum-free medium (the first $5 \mathrm{ml}$ were added over $5 \mathrm{~min}$ ). Cells were centrifuged for $10 \mathrm{~min}$ at $150 \mathrm{~g}$, resuspended in the medium containing $15 \%$ fetal calf serum, and distributed $(0.1 \mathrm{ml} /$ well $)$ into four microculture plates containing macrophages as feeder cells $\left(5 \times 10^{3} \mathrm{Balb} / \mathrm{c}\right.$ peritoneal exudate cells $/ 0.2 \mathrm{ml}$ well). Hybridomas were selected in hypoxanthineaminopterin-thymidine medium. Antirenin antibodies in the mouse's serum, culture supernatants, ascites, or purified fractions were detected by their binding to pure human renin.

SCREENING FOR RENIN ANTIBODIES. Renin antibodies were detected in mouse serum, culture medium, ascites, and purified IgG fractions. The two methods used were binding to iodinated renin in solution and a solid phase assay. For the binding with pure iodinated human renin, the separation of bound and free renin was by polyethylene-glycol, 8,000 mol wt (Sigma Chemical Co., St. Louis, MO), as described (4). lodinated renin was stable for 6 wks. Nonspecific binding was measured for each experiment and averaged $9 \%$. The titer of the antibody was defined as the dilution of the hybridoma culture medium that provided $50 \%$ of the maximum binding of tracer. For the solidphase assay, a $2-\mu \mathrm{g} / \mathrm{ml}$ solution of pure renin was adsorbed to the 
wells of a polyvinyl microplate overnight at $4^{\circ} \mathrm{C}$. The plates were washed, and supernatants of the hybridoma cultures were incubated in the renin-coated wells for $3 \mathrm{~h}$ at room temperature. Iodinated goatanti-mouse IgG (Tago Biosoft, Paris) was then added and incubated for $3 \mathrm{~h}$ at the same temperature. After extensive washings the wells were cut out and counted in a gamma scintillation counter.

HYBRIDOMA CLONING. Antibody-producing hybridomas were cloned and subcloned with a cloning cell sorter (FACS IV; BectonDickinson and Co., Becton-Dickinson FACS, Paramus, NJ).

MASS PRODUCTION OF MONOCLONAL ANTIBODIES. Ascites were produced after intraperitoneal injection of cloned hybridoma cells into pristane-treated Balb/c mice. Monoclonal antibodies were then purified from ascites by affinity chromatography on protein ASepharose (20), with an $85 \%$ recovery. The purity of the antibodies was assessed by both immunoelectrophoresis and isoelectrofocusing to be $>95 \%$. Isotypes were determined by immunoelectrophoresis with anti-subclass mice antibodies (Miles Laboratories, Inc., Elkhart, IN).

Table I identifies the seven different stable hybridomas obtained.

\section{Characterization of the antibodies}

INHIBITION OF RENIN ENZYMATIC ACTIVITY BY MONOCLONAL ANTIBODIES. The ability of monoclonal antibodies to inhibit PRA was tested on a pool of human plasma (PRA, $2.1 \mathrm{ng}$ angiotensin $\mathrm{I} / \mathrm{ml}$ per h). Plasma was incubated at $37^{\circ} \mathrm{C}$ with increasing dilutions of hybridoma culture medium (10- to 10,000 -fold final dilution) in $0.1 \mathrm{M}$ phosphate buffer, $\mathrm{pH} 7.4$, for $60 \mathrm{~min}$. Angiotensin I generated during the enzymatic reaction was then measured by RIA according to the method of Menard and Catt (21).

The control was the replacement of the antibody-containing culture medium by an identical volume of fresh culture medium. In each experiment, a comparative dilution curve was obtained whereby dilutions of R15 polyclonal antibodies replaced the culture medium.

KINETIC PROPERTIES OF MONOCLONAL ANTIBODIES. Scatchard determination. The association constant for the antibodies with human renin was determined by use of the supernatant of the culture media according to Scatchard (22). The concentrations of pure tumoral renin varied from $2 \times 10^{-8}$ to $1.5 \times 10^{-10} \mathrm{M}$. Pure iodinated human renin was used as the tracer. Separation of bound and free renin was performed with polyethylene-glycol (4).

Kinetics of renin inhibition. The kinetics of the inhibition of renin by 4G1- and 4B11-purified monoclonal antibodies were studied. 25 $\mu \mathrm{GU}$ of MRC human renin was incubated at $37^{\circ}, \mathrm{pH} 7.4$, with three different concentrations of a renin-free angiotensinogen prepared from human plasma as described $(10)\left(0.63 \times 10^{-6}, 0.42 \times 10^{-6}\right.$, and 0.21 $\left.\times 10^{-6} \mathrm{M}\right)$ in the presence of various concentrations of $4 \mathrm{Gl}(0.25$ to $\left.2.0 \times 10^{-9} \mathrm{M}\right)$ and $4 \mathrm{~B} 11\left(0.25\right.$ to $\left.3 \times 10^{-10} \mathrm{M}\right)$. Angiotensin I generated after 30 min of incubation was measured by RIA. Results were plotted according to the representations of Dixon, Webb, and LineweaverBurk (23).

SPECIFICITY OF MONOCLONAL ANTIBODIES. Direct RIA. This assay was performed to evaluate the capacity of monoclonal antibodies raised against human renin to bind renin of other species or to bind other acid proteases. The RIA of human renin was performed as described (4) by use of the supernatants of hybridoma culture $4 \mathrm{Gl}$ and $4 \mathrm{~B} 11$ as antibodies. Standard curves were obtained with pure human renin (1 to $100 \mathrm{ng}$ ). In the same assay were run purified human renal inactive renin ( 1 to $100 \mathrm{ng}$; see above, renin source $\mathrm{V}$ ); pure mouse submaxillary gland renin (24) (10-10,000 ng); pure hog renin (25) (10-1000 ng); porcine pepsin ( 0.01 to $10 \mu \mathrm{g})$ which was obtained from Sigma Chemical Co. and had a specific activity of $2,965 \mathrm{U} / \mathrm{mg}$ protein, using hemoglobin as substrate; and pure human cathepsin D (26) $(0.01$ to $10 \mu \mathrm{g})$, generously donated by Dr. A. J. Barrett (Cambridge, England).

Enzymatic assay. In this assay we determined the ability of $4 \mathrm{Gl}$ and $4 \mathrm{~B} 11$ monoclonal antibodies to inhibit the enzymatic activity of renin in various species. The PRA was determined at pH 7.4 in man, dog, hog, rabbit, mouse, rat, and monkey (Marmoset and Papio). Results are expressed as the percentage of angiotensin I generated per hour as compared with the level of angiotensin I generated in the absence of antibody.

\section{Applications of monoclonal antibodies}

ANALYTICAL AFFINITY CHROMATOGRAPHY. The purified IgG fractions of four separate monoclonal antibodies, F15, 1A15, 2D12, and $4 \mathrm{Gl}$, were coupled to Sepharose $4 B$ as described (27). $2 \mathrm{mg} \mathrm{IgG}$ were coupled per milliliter of moist gel. $88 \%$ of the IgG was effectively coupled to the gel. The immunoadsorbants were washed with $1 \mathrm{M}$ $\mathrm{NaCl}, 0.1 \mathrm{M}$ citrate-phosphate buffer, $\mathrm{pH} 4.5,6 \mathrm{M}$ urea, and water, and equilibrated in $0.1 \mathrm{M}$ phosphate buffer, $\mathrm{pH} 7.50 .5 \mathrm{ml}$ of each of the four gels was packed in Pasteur pipettes and tested for the ability to bind human renin. The renin preparation applied to the gels consisted of 3 to $5 \mathrm{GU}$ crude renal renin supplemented with $\sim 50,000$ cpm iodinated renin (compare renin source II). The columns were eluted with the following agents: $0.1 \mathrm{M}$ phosphate buffer, $\mathrm{pH} 7.5 ; 0.1$ $\mathrm{M}$ citrate-phosphate buffer, $\mathrm{pH} 4.5 ; 0.1 \mathrm{M}$ citrate-phosphate buffer, pH 4.5, containing $2 \mathrm{M} \mathrm{NaCl}$, followed by the same buffer containing 1 to $6 \mathrm{M}$ urea. The radioactivity of each eluant was counted and the renin concentration was measured by direct RIA (4).

The $4 \mathrm{G} 1$-gel was also tested for its ability to separate active from inactive renin. Different sources of inactive renin were used: $(a)$ the culture medium of chorionic cells, $5 \mathrm{ml}$ of which was applied to 0.5 $\mathrm{ml}$ of gel at $\mathrm{pH}$ 7.5. The gel was eluted with citrate-phosphate buffer, pH 4.5, then with $6 \mathrm{M}$ urea. Renin was measured in the fractions by direct RIA. Also used were $(b)$ renal inactive renin; and $(c)$ amniotic liquid $(2 \mathrm{ml})$ and plasma $(5 \mathrm{ml})$, which contain both active and inactive renin. In these experiments renin was measured in the fractions by the enzymatic assay before and after trypsin activation as described (28).

PURIFICATION OF HUMAN RENIN. The purified IgG fraction of F15 was coupled to cyanogen bromide-activated Sepharose 4B (27) by use of $10 \mathrm{mg} \mathrm{IgG/ml} \mathrm{of} \mathrm{moist} \mathrm{gel.} \mathrm{Haas} \mathrm{renin}(1,780 \mathrm{GU})$ was used as starting material. The renin sample was dialyzed twice against 25 vol of $0.1 \mathrm{M}$ phosphate buffer, $\mathrm{pH} 7.5$, and applied by gravity to a 1 $\times 13 \mathrm{~cm}$ column of gel equilibrated with the same buffer. The column was washed extensively with the starting buffer ( 10 bed vol), and renin was then eluted with $0.1 \mathrm{M}$ citrate-phosphate buffer, $\mathrm{pH} 4: 0$, containing $2.0 \mathrm{M} \mathrm{NaCl}$, at a flow rate of $0.3 \mathrm{ml} / \mathrm{min}$. After absorbance was measured at $280 \mathrm{~nm}$, each fraction was adjusted to $\mathrm{pH} 5.0$ with 0.7 $\mathrm{M} \mathrm{Na} \mathrm{PO}_{4}$, and three protease inhibitors were added at a final concentration of $3 \mathrm{mM}$ (benzamidine- $\mathrm{HCl}, \mathrm{Na}_{2}-\mathrm{EDTA}$, and sodium tetrathionate). The renin-containing fractions were pooled and concentrated by the use of a PM-10 membrane (Amicon Corp., Scientific Systems Div., Danvers, MA).

Renin was measured both by its enzymatic activity and by direct RIA. For the enzymatic activity, samples were diluted to a final renin concentration of $\sim 2 \times 10^{-5} \mathrm{GU} / \mathrm{ml}$. The assays were standardized with the MRC renin standard and the results were expressed as Goldblatt units per milliliter. The direct RIA was performed with pure human renin ( 25 to $800 \mathrm{pg} /$ tube) as the standard. Samples were diluted in RIA buffer $(0.1 \mathrm{M}$ phosphate buffer, $\mathrm{pH} 7.5$, containing $1 \mathrm{mg} / \mathrm{ml}$ 
BSA). In addition, a modified RIA, the rapid RIA, was used to screen chromatographic fractions. The equilibration time was reduced to $2 \mathrm{~h}$ at $20^{\circ} \mathrm{C}$ by decreasing the sensitivity (standard curve, 0.43 to $6.9 \mathrm{ng}$ renin/tube) and increasing the concentration of antiserum. The results of both methods (i.e., the sensitive and the rapid RIA) are expressed as Goldblatt units per milliliter, based on a specific activity for pure renin of $810 \mathrm{GU} / \mathrm{mg}$ protein. Protein was measured by a slight modification of the method of Lowry et al. (29), with crystalline BSA (Sigma Chemical Co.) as standard. To maximize the sensitivity of the method, the total reaction volume was reduced to $1.2 \mathrm{ml}$, permitting samples of up to $100 \mu \mathrm{l}$, and absorbance was measured at $750 \mathrm{~nm}$. The standard curve was linear between 1 and $15 \mu \mathrm{g}$ BSA.

IMMUNOFLUORESCENCE AND IMMUNOPEROXIDASE. Human and monkey renal cortex were fixed in Bouin's solution and embedded in paraffin. After they were washed in phosphate buffered saline (PBS)BSA, the slices were incubated with $1 \mathrm{~A} 12$ or $2 \mathrm{D} 12$ purified monoclonal antibodies. After a washing with PBS-BSA, the preparations were incubated with goat IgG-fluorescein isothiocyanate conjugated antimouse IgG (Miles Laboratories, Inc.). Counter staining was with $0.01 \%$ Evans blue. The peroxidase-antiperoxidase (PAP) technique was that of Sternberger (30). The first incubation was with $1 \mathrm{~A} 12$ or $2 \mathrm{D} 12$ purified antibodies and the second was with goat IgG anti-mouse IgG (Miles Laboratories, Inc.); the third incubation was with mouse-PAP (Miles Laboratories, Inc.). Diaminobenzidine $\mathrm{H}_{2} \mathrm{O}_{2}$ was used as a chromogenic substrate for the peroxidase. The nuclei were stained with hematoxylin.

The negative control was the replacement of the monoclonal renin antibodies (1A12 or 2D12) by the anti-dinitrophenol monoclonal antibody. The positive control was the use of polyclonal renin antibodies (R15) instead of the monoclonal antibodies.

RADIOIMMUNOMETRIC ASSAY OF RENIN. The radioimmunometric assay measured renin in a sandwich between two monoclonal renin antibodies. The first unlabeled monoclonal antibody was coated on the plates and the second one was iodinated.
Monoclonal antibodies were iodinated by use of the chloramine $T$ method (31). Iodinated antibodies were further purified on Sephacryl S 300. The labeled antibodies had a specific activity of $15 \mu \mathrm{Ci} / \mu \mathrm{g}$.

The assays were performed on polyvinyl microtitration plates (Falcon Labware, Div. Becton-Dickinson and Co., Oxnard, CA). The plates were coated with the first monoclonal antibody $(50 \mu \mathrm{g} / \mathrm{ml})$, incubated for $18 \mathrm{~h}$ at $4^{\circ} \mathrm{C}$, washed several times, and then incubated with $150 \mu \mathrm{l}$ of renin samples or human plasma for $24 \mathrm{~h}$ at $4^{\circ} \mathrm{C}$. $200,000 \mathrm{cpm}$ of the second monoclonal antibody were added and incubated for $24 \mathrm{~h}$ at $4^{\circ} \mathrm{C}$. The wells were then cut and counted in a gamma scintillation counter.

Twenty-four distinct pairs of monoclonal antibodies were tested to select the pair that provided the higher sensitivity in renin assay. The F15 antibody was not tested in the immunometric screening, owing to its low affinity for renin.

\section{Results}

\section{Fusions}

As shown in Table $I$, the quantity, the source, and the manner of administration of human renin changed from one fusion to another. The first three fusions were performed with spleen cells from Balb/c mice injected with pure tumoral renin. This protocol resulted in the production of only one stable monoclonal antibody, F15. The last two fusions were performed with the spleen cells from high-responder Biozzi mice. In the case of the F37 fusion, the mouse was first injected with tumoral renin and boostered with renal renin. The Biozzi mouse used for the F55 fusion was injected exclusively with renal renin. Both Biozzi mice had high levels of circulating renin antibodies (compare Table I). Fusions F37 and F55 resulted in the production of two and four stable monoclonal antibodies, respectively.

Table I. Preparation and Yield of Antirenin Lymphocyte Hybridization

\begin{tabular}{|c|c|c|c|c|c|}
\hline & \multicolumn{5}{|l|}{ Fusion code } \\
\hline & F15 & F22 & F29 & F37 & F55 \\
\hline Mouse strain & Balb/c & Balb/c & Balb/c & Biozzi & Biozzi \\
\hline Immunization protocol & $\begin{array}{l}5 \mu \mathrm{g} \text { SC TR } \\
2 \mu \mathrm{g} \text { IV TR } \\
1 \mu \mathrm{g} \text { IV TR }\end{array}$ & $\begin{array}{c}15 \mu \mathrm{g} \text { SC TR } \\
3 \mu \mathrm{g} \text { SC TR } \\
10 \mu \mathrm{g} \text { SC TR } \\
3 \mu \mathrm{g} \text { (IV-IP) TR }\end{array}$ & $\begin{array}{c}10 \mu \mathrm{g} \text { SC TR } \\
7 \mu \mathrm{g} \text { SC TR } \\
5 \mu \mathrm{g} \text { IV TR } \\
10 \mu \mathrm{g} \quad \mathrm{TR} \\
\text { (in vitro) }\end{array}$ & $\begin{array}{l}10 \mu \mathrm{g} \text { SC TR } \\
10 \mu \mathrm{g} \text { SC RR } \\
10 \mu \mathrm{g} \text { SC RR } \\
68 \mu \mathrm{g} \text { (IV-IP) RR }\end{array}$ & $\begin{array}{c}10 \mu \mathrm{g} \text { SC RR } \\
10 \mu \mathrm{g} \text { SC RR } \\
5 \mu \mathrm{g} \text { SC RR } \\
2 \times 30 \mu \mathrm{g} \text { SC RR } \\
25 \mu \mathrm{g} \text { IV RR }\end{array}$ \\
\hline $\begin{array}{l}\text { Dilution of mouse } \\
\text { serum for } 50 \% \\
\text { binding to iodinated } \\
\text { renin }\end{array}$ & $1 / 2,500$ & $1 / 5,000$ & ND & $1 / 10,000$ & $1 / 120,000$ \\
\hline Antibodies code & $\mathrm{F} 15$ & None & None & $\begin{array}{l}\text { 1A12 } \\
2 \mathrm{D} 12\end{array}$ & $\begin{array}{l}3 \mathrm{E} 8 \\
4 \mathrm{~B} 11 \\
41 \\
4 \mathrm{G} 1\end{array}$ \\
\hline
\end{tabular}

TR, tumoral renin; RR, renal renin; SC, subcutaneous injection; IV intravenous injection; IP, intraperitoneal injection; ND, not determined. 


\section{Characterization of monoclonal antibodies}

Binding to human renin. The hybridoma supernatants were screened repeatedly for their ability to bind iodinated renin. In the case of F37 and F55 fusions the supernatants were simultaneously screened in the solid phase assay. This latter procedure detected the 2D12 because this hybridoma supernatant bound strongly to insolubilized renin but did not bind at all to iodinated renin. All the other monoclonal antibodies were detected by their binding to iodinated renin. Their ability to bind renin varied with the antibody concentration in the hybridoma supernatants. The binding kinetics could be determined only by use of purified antibodies; the results are shown in Fig. 1. In most cases monoclonal antibodies did not provide $100 \%$ binding to iodinated renin, and a plateau was reached at $90 \%$ binding. A dilution curve of antibodies was used to find the concentration that gave 50\% binding: $1 \times 10^{-10}(3 \mathrm{E} 8)$, $1.5 \times 10^{-10}$ (4B11), $2 \times 10^{-10}$ (4E1), $3.5 \times 10^{-10}(4 \mathrm{G} 1), 5$ $\times 10^{-10}$ (1A12), $3 \times 10^{-8}$ (F15), and $9 \times 10^{-8} \mathrm{M}$ (2D12).

Antibody 2D12 provided an interesting exception. It was obtained from ascites, concentrated, and purified. It bound soluble iodinated renin much less $\left(3 \times 10^{-8} \mathrm{M}\right.$ detected $)$ than the insoluble renin of the solid phase assay $\left(10^{-11} \mathrm{M}\right.$ detectable) (Fig. 2).

Association constants, $\mathrm{Ka}$, measured by Scatchard's method, were respectively, $5 \times 10^{6}, 5 \times 10^{8}, 1.2 \times 10^{9}$, and $1.3 \times 10^{9}$ $\mathrm{M}^{-1}$ for the antibodies F15, 4E1, 3E8, and $1 \mathrm{~A} 12$. No determination could be performed for either $4 \mathrm{G} 1$ or $4 \mathrm{~B} 11$, as no linear regression curves of bound/free vs. bound iodinated renin were obtained.

Inhibition of renin enzymatic activity. The ability of the monoclonal antibodies to inhibit the enzymatic activity of

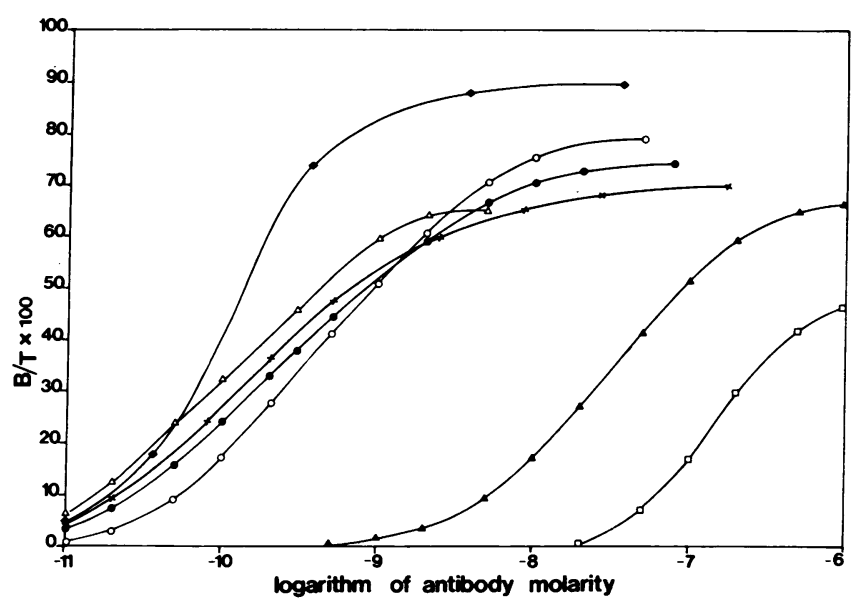

Figure 1. Binding of monoclonal antibodies to iodinated renin. Purified IgG fractions of monoclonal antibodies $\left(10^{-11}\right.$ to $\left.10^{-6} \mathrm{M}\right)$ were tested for their ability to bind iodinated human renin. The logarithm of antibody molarities is plotted against the percentage of bound iodinated renin (B/T, bound vs. total). ๑, 4G1; 0, 1A12; •, 3E8; $\triangle, 4 \mathrm{~B} 11 ; \triangle, \mathrm{F} 15$; $\mathrm{C}, 2 \mathrm{D} 12$; and $\times$, 4E1.

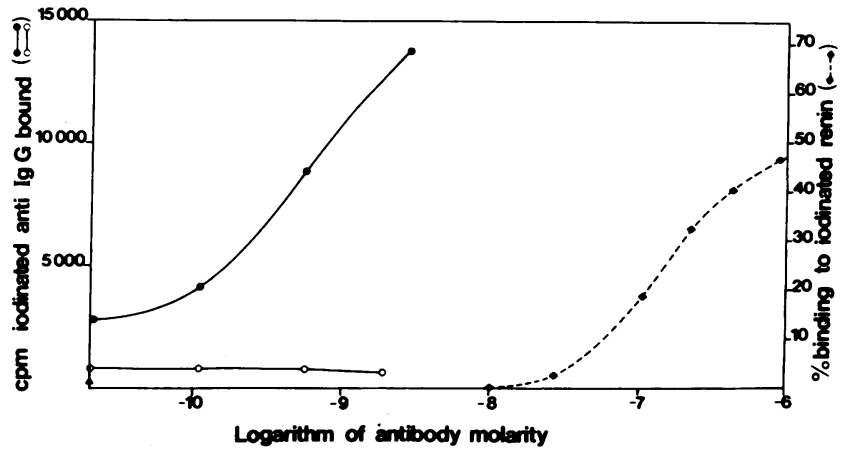

Figure 2. Comparative binding of 2D12 antibody to soluble and insolubilized renin. 2D12 concentrations $\left(10^{-11}\right.$ to $\left.10^{-6} \mathrm{M}\right)$ are expressed as logarithms. The binding of 2D12 to renin insolubilized on polyvinyl microplate is given in counts per minute of iodinated goat anti-mouse IgG bound to the wells (left ordinate). $\bullet$, plates coated with $2 \mu \mathrm{g} / \mathrm{ml}$ human renin. $O$, plate coated without renin. $\Delta$ indicates the nonspecific binding of labeled anti-IgG to the plates coated with renin in the absence of monoclonal antibodies. The binding of 2D12 to soluble renin (right ordinate) is expressed as the percentage of bound iodinated renin (४).

human renal and plasma renin was studied. There was no inhibition with antibodies $1 A 12,2 D 12,3 E 8$, and 4E1. However $\mathrm{F} 15,4 \mathrm{~B} 11$, and $4 \mathrm{G} 1$ inhibited renin activity. Fig. 3 shows the inhibition of PRA with various dilutions of the hybridoma supernatants. F15 inhibited weakly whereas $4 B 11$ and 4G1 were potent inhibitors; $50 \%$ inhibition was obtained at $1 / 100$ and $1 / 600$-fold dilutions for $4 \mathrm{G} 1$ and $4 \mathrm{~B} 11$, respectively.

The kinetics of renin inhibition by pure $4 \mathrm{Gl}$ and $4 \mathrm{~B} 11$ are given in Fig. 4. The different representations show that both antibodies act as noncompetitive inhibitors of renin

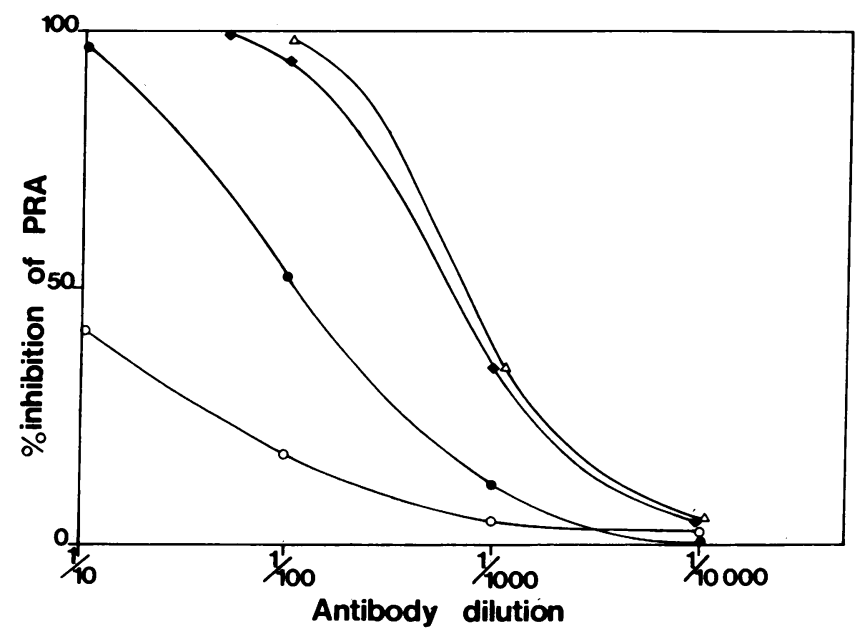

Figure 3. Inhibition of renin enzymatic activity. On the abscissa, the dilution of hybridoma supernatants and of antiserum is represented by $\bullet, 4 \mathrm{G} 1$; $0, \mathrm{~F} 15 ; \bullet, 4 \mathrm{~B} 11$; and $\Delta, \mathrm{R} 15$. 

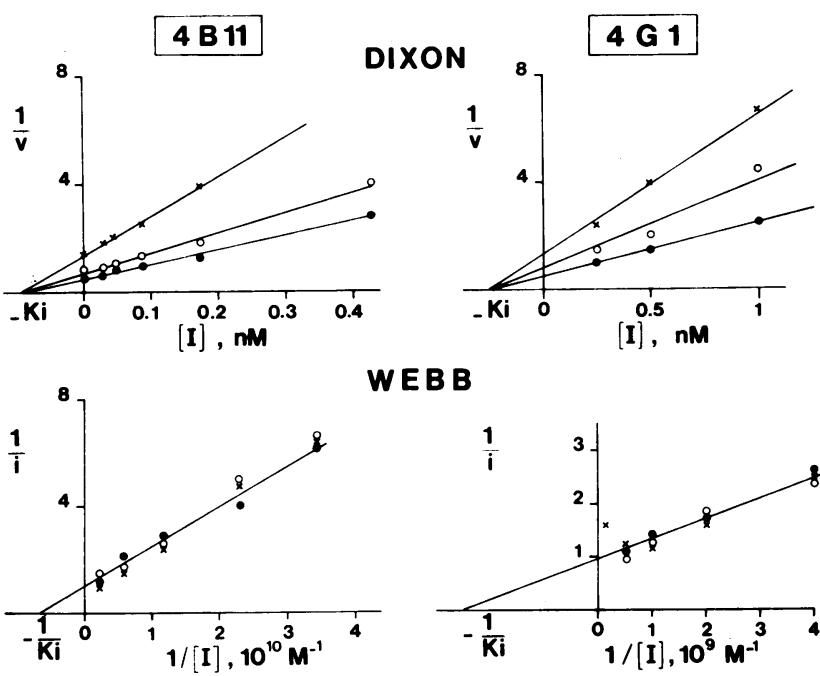

WEBB

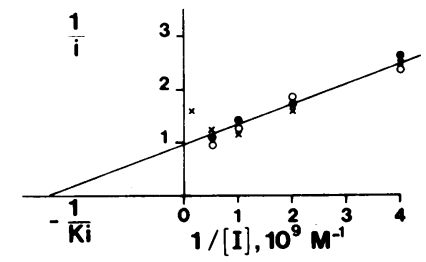

LINEWEAVER-BURK
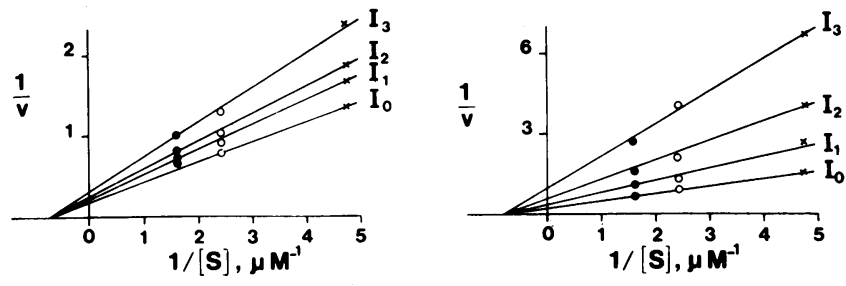

Figure 4. Kinetic representation of the inhibition of renin enzymatic activity by $4 \mathrm{Gl}$ and $4 \mathrm{~B} 11$ antibodies. $\mathrm{V}$ is the reaction velocity expressed in nanograms angiotensin I generated in $30 \mathrm{~min}$ of incubation. $S$ is the angiotensinogen concentration: $\times, 0.21 \mu \mathrm{M} ; 0,0.42$ $\mu \mathrm{M}$; and $\bullet, 0.63 \mu \mathrm{M}$. The fractional inhibition (1/I) is $1-\mathrm{Vi} / \mathrm{Vo}$, where $\mathrm{Vi}$ is the velocity in the presence of inhibitor and Vo the velocity in the absence of inhibitor. I is the concentration of monoclonal antibody. In the case of the Lineweaver-Burk representation, the $4 B 11$ concentrations are $I_{0}=0 ; I_{1}=29 \times 10^{-11} ; I_{2}=4.3$ $\times 10^{-11}$; and $I_{3}=8.6 \times 10^{-11} \mathrm{M}$. The $4 \mathrm{Gl}$ concentrations were $I_{1}$ $=2.5 \times 10^{-10} ; \mathrm{I}_{2}=5 \times 10^{-10} ;$ and $\mathrm{I}_{3}=10^{-9} \mathrm{M}$. Each point represents the mean of two separate determinations.

enzymatic activity. The $K i$ calculated for the three different representations varied between $2.5 \times 10^{-10}$ and $4 \times 10^{-10} \mathrm{M}$ for $4 \mathrm{Gl}$ and between $1.0 \times 10^{-10}$ and $1.8 \times 10^{-10} \mathrm{M}$ for $4 \mathrm{~B} 11$.

Specificity for renin. Fig. 5 shows the standard curves for a human renin RIAs performed with $4 \mathrm{G} 1$ and $4 \mathrm{~B} 11.0 .1 \mathrm{nM}$ active renin was detected when $4 \mathrm{~B} 11$ was used, as compared with $0.5 \mathrm{nM}$ when $4 \mathrm{G} 1$ was used. In contrast, neither $50 \mathrm{nM}$ hog renin nor $500 \mathrm{nM}$ mouse renin bound to these two antibodies, nor was there any binding of $500 \mathrm{nM}$ of the acid proteases pepsin and cathepsin $\mathrm{D}$ to any of the antibodies.

The specificity of $4 \mathrm{Gl}$ and $4 \mathrm{~B} 11$ antibodies for human renin was further confirmed by the low percentage of PRA inhibition by the antibodies in the dog, hog, rabbit, mouse, and rat (Table II). However, both antibodies inhibited monkey renin in Papio and Marmoset strains.

Behavior of active and inactive renin on immunoaffinity

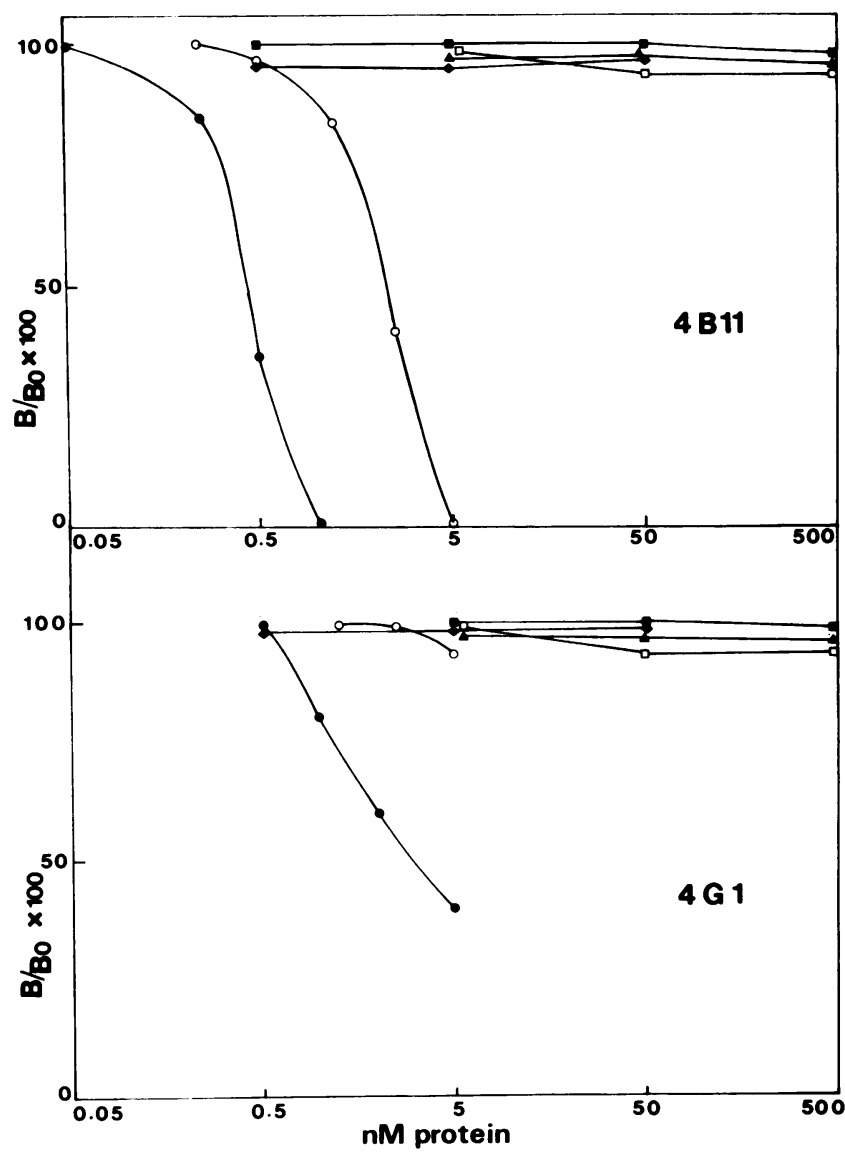

Figure 5. Determination of the specificity of $4 \mathrm{~B} 11$ and $4 \mathrm{G} 1$ antibodies. RIA of human renin using $4 \mathrm{~B} 11$ and $4 \mathrm{Gl}$ as antibodies. $\bullet$, pure human tumoral renin; $O$, inactive renin purified from human kidney; $\bullet$, hog renin; $a$, mouse submaxillary gland renin; $\triangle$, human cathepsin $\mathrm{D}$; and $\mathrm{\square}$, hog pepsin. $\mathrm{B} / \mathrm{B}_{0}$, bound/unbound.

gels. Fig. 6 summarizes the behavior of active renin on the four immunoadsorbants. The 2D12 gel did not retain renin, but the other three gels bound both iodinated and crude renal renin. However, up to $18 \%$ of iodinated renin was not retained at $\mathrm{pH}$ 7.5. Renin adsorbed on 1A12- and F15-gels was easily eluted at $\mathrm{pH} 4.5$ in the presence of $2 \mathrm{M} \mathrm{NaCl}$, whereas the enzyme was not removed from the 4Gl-gel under these conditions. In separate experiments conducted at neutral $\mathrm{pH}$, elution was obtained with $1 \mathrm{M}$ urea for the F15-gel, but $6 \mathrm{M}$ urea was required to elute renin from the $4 G 1$ and $1 A 12$-gels. The recovery of active renin in the dialyzed urea fraction averaged $80 \%$.

Inactive renin from chorionic cell culture was also fixed on 4G1-gel, as shown in Fig. $7 A$ and was easily eluted when the $\mathrm{pH}$ was decreased to 4.5. A similar pattern was obtained for the elution of renal inactive renin (Fig. 7 D). Active renin was much more strongly retained on the same gel, requiring $6 \mathrm{M}$ urea for elution (compare Fig. 6). 
Table II. Percentage Inhibition of Plasma Renin Activity

\begin{tabular}{llc}
\hline & $\begin{array}{l}4 \mathrm{G} 1 \\
\left(8 \times 10^{-9} \mathrm{M}\right)\end{array}$ & $\begin{array}{l}4 \mathrm{~B} 11 \\
\left(2 \times 10^{-9} \mathrm{M}\right)\end{array}$ \\
\hline Man & 100 & 100 \\
Monkeys & & \\
$\quad$ Marmoset & 82 & 100 \\
Papio & 85 & 100 \\
Dog & 5 & 0 \\
Rat & 3 & 2 \\
Hog & 0 & 0 \\
Mouse & 0 & 0 \\
Rabbit & 1 & 8 \\
\hline
\end{tabular}

Renins from amniotic fluid (Fig. 7 B) and plasma (Fig. 7 $C$ ) were also retained on the $4 \mathrm{Gl}$-gel. In both cases the renin eluted at pH 4.5 was highly activatable by trypsin treatment

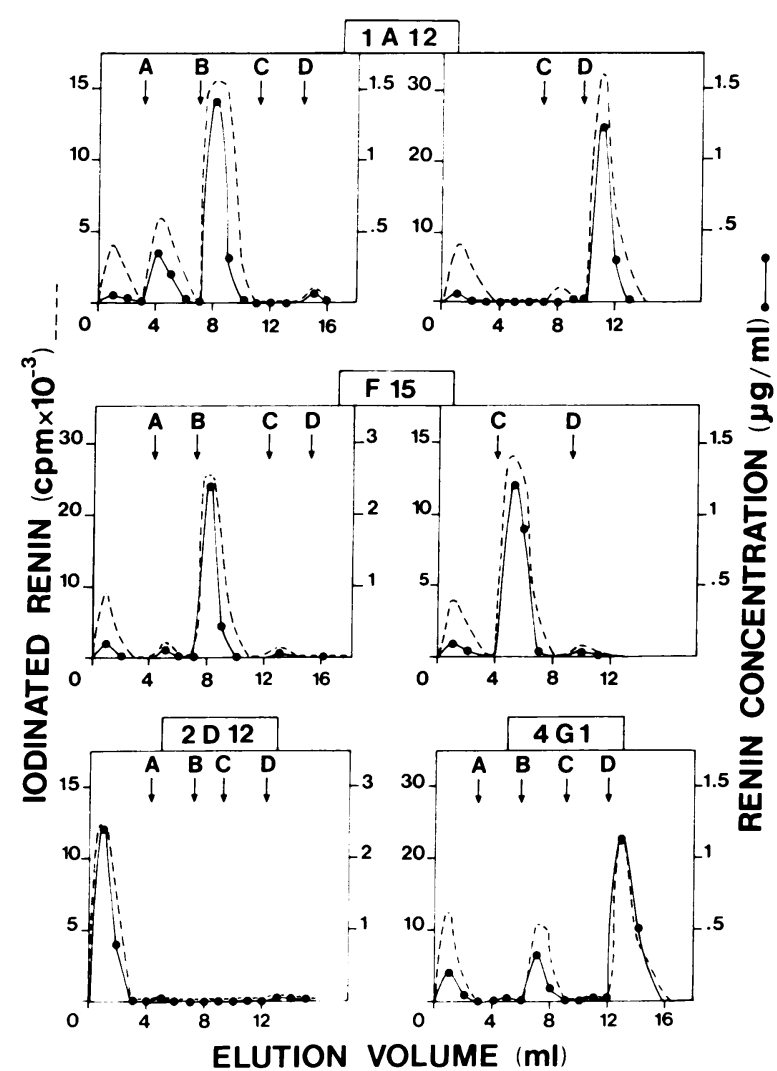

Figure 6. Immunopurification of active renin with monoclonal antibodies. 4G1, 1A12, 2D12, and F15 antibodies were coupled to Sepharose 4B. $0.5-\mathrm{ml}$ gel columns were equilibrated at $\mathrm{pH} 7.5$ and used to purify human renin (3.0-5.0 GU active renin containing iodinated renin). Eluting agents were $(A) 0.1 \mathrm{M}$ phosphate-citrate buffer, $\mathrm{pH} 4.5 ;(B) 0.1 \mathrm{M}$ phosphate-citrate buffer, $\mathrm{pH} 4.5$, containing $2 \mathrm{M} \mathrm{NaCl} ;(C) 1 \mathrm{M}$ urea; and $(D) 6 \mathrm{M}$ urea. - - -, elution pattern of iodinated renin. $\bullet$, elution pattern of renin measured by direct RIA. (8-fold and 13-fold increase, respectively, for amniotic fluid and plasma). By contrast, active renin eluted in the urea fraction could not be activated by trypsin treatment. The recovery of renin in the purified fractions varied from 80 to $86 \%$. It was not possible to calculate the purification factor because albumin was used in the elution buffer as a carrier.

Purification of human renin. In pilot experiments, the capacity of the F15-gel for Haas step $\mathrm{V}$ renin was estimated to be $\sim 150 \mathrm{GU} / \mathrm{ml}$ gel. Accordingly, the crude material available for purification was fractionated and the maximum quantity was applied to the gel each time to avoid dilution of eluted renin. 1,780 GU was applied to a 10-ml gel. Most of the protein appeared in the breakthrough fractions, whereas renin eluted with pH 4.0 buffer (Fig. 8). By the pooling of the fractions with the highest specific activity, a preparation was obtained with a specific activity of $109 \mathrm{GU} / \mathrm{mg}$, representing a 825 -fold enrichment with a yield of $53 \%$. In another preparation 2,200 GU Haas renin was applied to the affinity gel. The renin obtained had a specific activity of $81 \mathrm{GU} / \mathrm{mg}$ protein, corresponding to a 787 -fold purification. This material was used for the immunization of mice in fusion F37 and F55 and was stable at $-80^{\circ} \mathrm{C}$ for more than $1 \mathrm{yr}$.

Immunohistochemical localization of renin. The 2D12 antibody $(170 \mu \mathrm{g} / \mathrm{ml})$ stained renin in the macaque kidney by the indirect immunofluorescence method. Fluorescence was observed in the epithelioid cells of the afferent artery (Fig. 9 $A)$. By the same technique the 2D12 antibody $(170 \mu \mathrm{g} / \mathrm{ml})$ detected renin in human kidney. Fluorescence was observed in arteriolar cells close to the macula densa (Fig. $9 \mathrm{~B}$ ). With the PAP technique the $1 \mathrm{~A} 12$ antibody $(750 \mu \mathrm{g} / \mathrm{ml})$ stained renin in the human kidney, and clusters of renin cytoplasmic granulation were found in the cells of afferent arterioles (Fig. 9 C).

No fluorescence was obtained in macaque and human kidney when monoclonal antibodies to human renin were replaced by an anti-dinitrophenol monoclonal antibody.

Table III summarizes the properties and applications of the seven monoclonal antibodies in comparison with those previously reported for the polyclonal antibody R15 $(5,32,33)$.

Radioimmunometric assay of renin. In a first series of experiments, the binding of renin by various pairs of antibodies was screened at a high concentration of renin ( $34 \mathrm{ng} /$ well), as shown in Table IV. 13 pairs of antibodies bound renin, another pair bound only slightly. As expected, when the second antibody tested was the same as the first one, no signal was obtained. This accounted for 4 of the 10 negative pairs. In a second series of experiments the 13 positive pairs were tested for their ability to detect decreasing amounts of renin (down to 6.25 $\mathrm{pg} /$ well). The two most efficient pairs were $4 \mathrm{~B} 11-4 \mathrm{G} 1$ and 3E8-4G1. Fig. 10 represents the standard curve for a renin assay that used the $3 \mathrm{E} 8-4 \mathrm{Gl}$ pair of monoclonal antibodies. Standard curves were constructed with pure human renin in buffer and renin free plasma (10). A linear curve was obtained for renin concentrations between 0 and $240 \mathrm{pg} /$ well (Fig. 10 

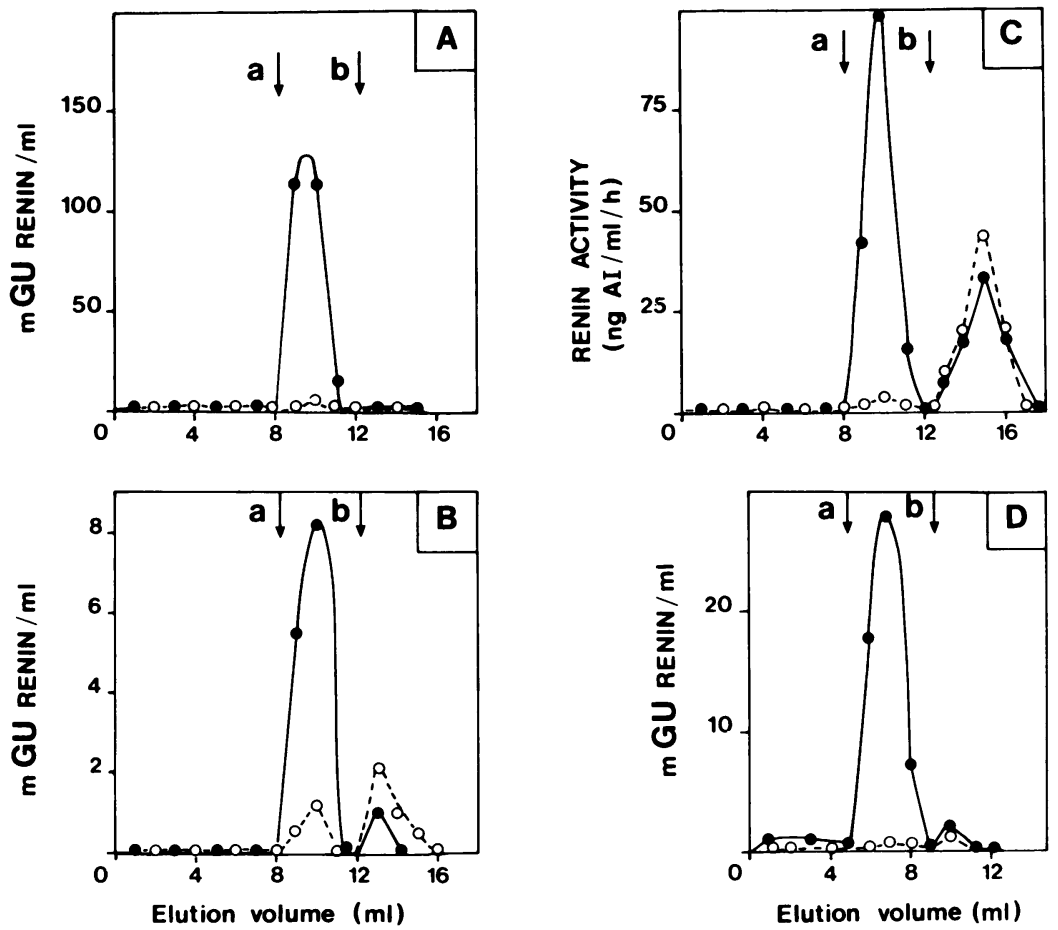

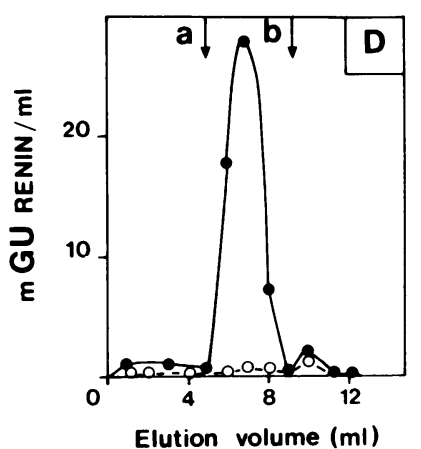

Figure 7. Concomitant separation and purification of active and inactive renin on $4 \mathrm{Gl}$ gel. Elution pattern of samples equilibrated in $0.1 \mathrm{M}$ phosphate buffer, pH 7.5, and applied to a $0.5-\mathrm{ml}$ gel column. The arrows indicate the changes of eluting agents: $(a) 0.1$ $\mathrm{M}$ phosphate-citrate buffer $\mathrm{pH} 4-5$; and (b) $6 \mathrm{M}$ urea. $1 \mathrm{ml}$ fractions were collected and renin was assayed, before (o) or after ( $\bullet$ ) trypsin treatment by enzymatic measurement. $A$, medium of chorionic cell culture ( 5 $\mathrm{ml}) ; B$, amniotic liquid $(2 \mathrm{ml}) ; C$, plasma $(5 \mathrm{ml}) ;$ and $D$, inactive renin purified from human kidney $(1 \mathrm{ml})$.
$A$ ). Fig. $10 \mathrm{~B}$ emphasizes the linearity of the curve at low renin concentrations (between 0 to $15 \mathrm{pg} /$ well). The sensitivity of this new assay is $3 \mathrm{pg} /$ well, i.e., $20 \mathrm{pg} / \mathrm{ml}$ plasma. Renin was detected in the plasma of 10 normal volunteers tested. Dilutions

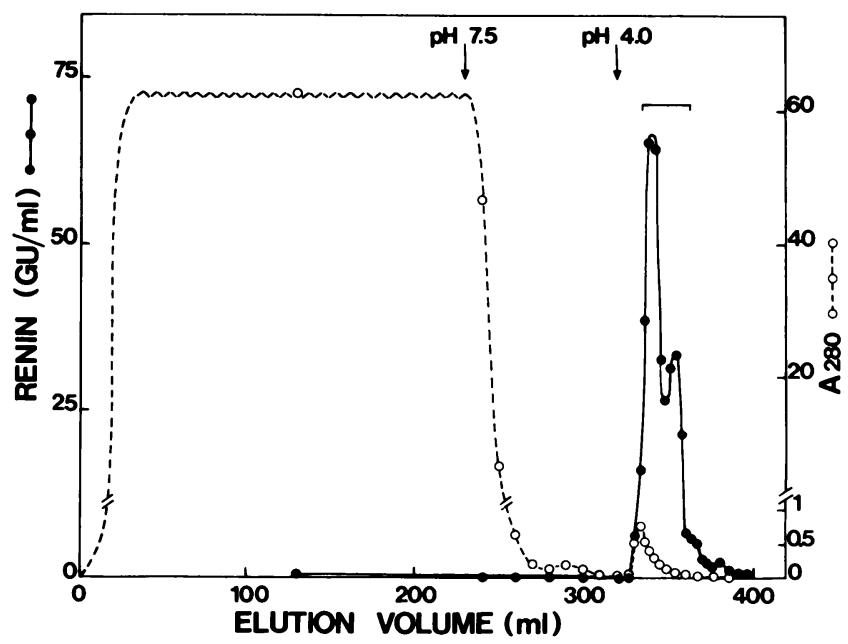

Figure 8. Purification of Haas step V renin on F15-sepharose. Renin was measured in the fractions by the enzymatic activity assay. The horizontal bracket indicates the fractions that were pooled and concentrated. of plasma paralleled the standard curve built in renin free plasma.

Similar results were obtained when the $4 \mathrm{~B} 11-4 \mathrm{G} 1$ pair of antibodies was used (data not shown).

\section{Discussion}

Five fusions gave only seven stable monoclonal antibodies against human renin. This may indicate the low antigenicity of human renin. It is difficult to compare the efficiency of the different fusions because the protocols differed: the first fusion was performed on the spleen cells of a Balb/c mouse injected with only $6.2 \mu \mathrm{g}$ pure tumoral renin whereas the last fusion was performed with the cells of a Biozzi mouse injected with $115 \mu \mathrm{g}$ of renal renin 10 times less pure. Nevertheless, results obtained with the Biozzi mice seem better, as six monoclonal antibodies were obtained with two fusions vs. only one with three fusions of Balb/c spleen cells. Similar differences were found for anti-human chorionic gonadotropin monoclonal antibodies (34).

Six of our seven antibodies were mass produced in ascitic fluid. However, the production of $4 \mathrm{~B} 11$ in ascites gave low concentrations of antibodies, requiring an in vitro method of production to be set up.

Antibodies were screened by their capacity to bind pure iodinated renin. This test was chosen because of the availability of pure renin and because of its simplicity and reproducibility. 

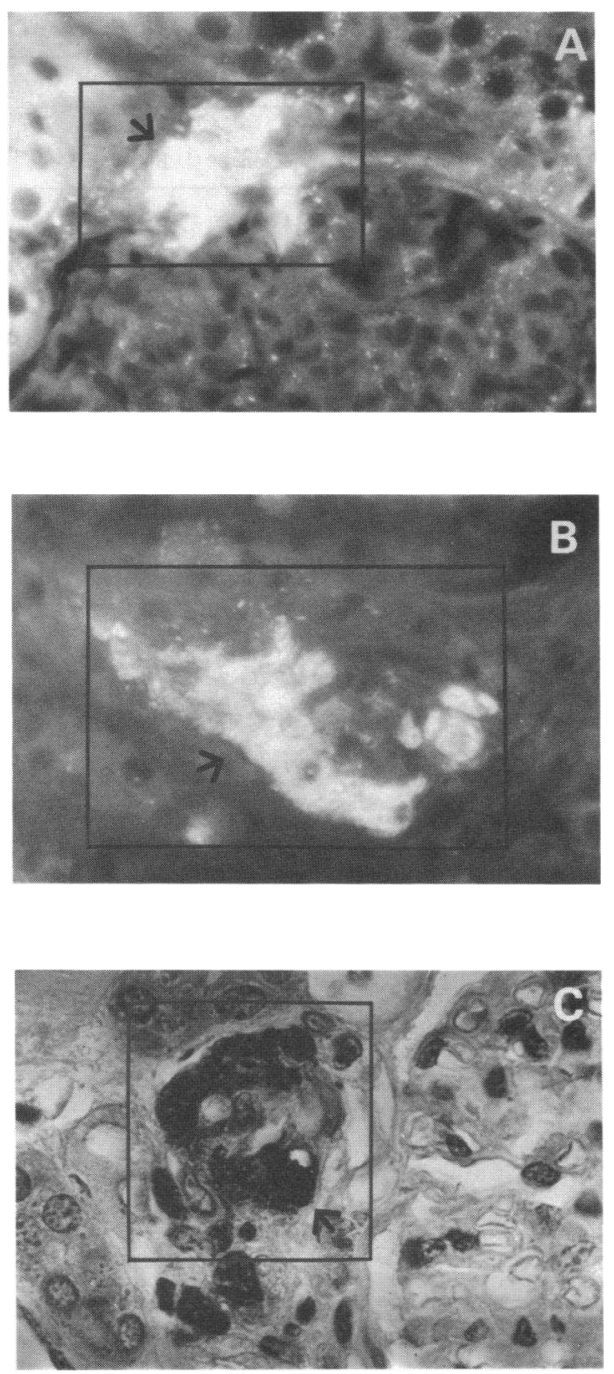

Figure 9. Photomicrographs of kidneys stained with monoclonal antibodies to human renin. $A$, macaque kidney stained by the indirect fluorescence technique using the 2D12 antibody. Staining for renin (arrow) was obtained in the cells of the afferent arteriole. Original magnification $\times 160$. B, human kidney stained by the indirect fluorescence technique using the 2D12 antibody. Renin fluorescence (arrow) was found in the arteriolar cell close to the macula densa. Original magnification $\times 250$. $C$, human kidney stained by the PAP procedure using the $1 \mathrm{~A} 12$ antibody. Clusters of renin cytoplasmic granulations (arrow) were observed into the cells of the afferent arteriole. Original magnification $\times 320$.

It allowed the detection of six of seven antibodies in the hybridoma culture medium. In the present study the antibody titer paralleled the association constant. However, the use of iodinated renin for the screening and studying of renin monoclonal antibodies had its limitations. The association constant of antibodies 4G1 and 4B11 could not be determined, as no regression curve could be drawn. This may have been due to the fact that the epitope on the enzymatically active renin was modified by iodination, leading to a decrease in binding by the antibodies. Modifications of the renin molecule during iodination might also explain the inability of most monoclonal antibodies to provide $100 \%$ binding of the tracer. The use of iodinated renin for screening monoclonal antibodies probably resulted in an underestimation of the number of antibodies. This is illustrated by the antibody 2D12, which was detected in the culture supernatant only by the solid phase assay. Again, the poor binding of iodinated renin by this antibody could be due to alteration of the renin molecule during iodination. Alternatively, the 2D12 antibody may recognize only insoluble renin, not soluble renin. Indeed, 2D12 coupled to Sepharose retains neither iodinated nor unlabeled renal renin whereas it stains renin fixed in the juxtaglomerular cells of the afferent artery of human kidney. It is therefore possible that the insolubilization of renin would induce a structure modification, i.e., the unmasking of an epitope that was recognized by $2 \mathrm{D} 12$.

The immunometric screening gave us a new opportunity to demonstrate that our antibodies are actually monoclonal antibodies, i.e., that they are directed against a single epitope. Table IV demonstrates that no signal can be obtained in the immunometric assay when the first and the second antibodies are identical. This also shows that only one copy of the epitope is present in the renin molecule.

Three of seven antibodies inhibited the enzymatic activity of renal and plasma renin. This proportion appears high for, as monoclonal antibodies are directed against a unique antigenic site, there is a low probability that this site would involve the active site of the enzyme. For example, 1 of 5 antibodies inhibited the enzymatic activity of cyclic GMP-stimulated cyclic nucleotide phosphodiesterase (35) and 3 of 16 antibodies inhibited the activity of DNA polymerase (36). By contrast, Dzau et al. (37) recently reported that five of their six clones that secreted anti-human renin antibodies were inhibitors of the enzymatic activity.

Two of our antibodies, $4 \mathrm{Gl}$ and 4B11, are powerful inhibitors of renin. Kinetic studies demonstrated that they behaved as tight binding inhibitors $\left(K \mathrm{~K}<10^{-6} \mathrm{M}\right)$. The analyses of the kinetics based on the Michaelis-Menten equation are still valid, as the concentration of inhibitor that is free in solution is the same as the total inhibitor concentration; i.e., the total enzyme concentration $(E t)$ divided by $K i$ was $<0.01$ as calculated by Henderson et al. (38). In our experiments, $E \mathrm{t}$, total renin concentration, was $1 \times 10^{-12} \mathrm{M}$ and $\mathrm{Ki}$ was $>1 \times 10^{-10} \mathrm{M}$. Therefore, $E \mathrm{t} / \mathrm{Ki}$ was $<0.01$. The results obtained with the representations of Lineweaver-Burk, Dixon, and Webb were all consistent for a noncompetitive inhibition for both $4 \mathrm{~B} 11\left(\mathrm{Ki}=3 \times 10^{-10} \mathrm{M}\right)$ and $4 \mathrm{Gl}\left(\mathrm{Ki}=1 \times 10^{-10}\right.$ $M)$. So it seems that both of these antibodies, when bound, either hinder the access of the active site or alter its catalytic mechanism. They are not directed against the active site itself. 
Table III. Renin Antibodies: Properties and Applications

\begin{tabular}{|c|c|c|c|c|c|c|c|c|}
\hline & \multicolumn{8}{|c|}{ Antibodies code } \\
\hline & $\begin{array}{l}\text { F15 } \\
\text { Monoclonal }\end{array}$ & $\begin{array}{l}\text { 1A12 } \\
\text { Monoclonal }\end{array}$ & $\begin{array}{l}\text { 3E8 } \\
\text { Monoclonal }\end{array}$ & $\begin{array}{l}\text { 4BII } \\
\text { Monoclonal }\end{array}$ & $\begin{array}{l}\text { 4EI } \\
\text { Monoclonal }\end{array}$ & $\begin{array}{l}\text { 4G1 } \\
\text { Monoclonal }\end{array}$ & $\begin{array}{l}\text { 2D2 } \\
\text { Monoclonal }\end{array}$ & $\begin{array}{l}\text { R15 } \\
\text { Polyclonal }\end{array}$ \\
\hline Isotype & IgGI & IgGI & IgGI & IgG1 & IgG2a & IgGI & IgGI & ND \\
\hline $\begin{array}{l}\text { Antibody concentration for } \\
50 \% \text { binding of } \\
\text { iodinated renin }(n M)\end{array}$ & 30 & 0.5 & 0.10 & 0.15 & 0.20 & 0.35 & 90 & $\begin{array}{l}200,000 \text {-fold } \\
\text { dilution } \\
\text { of plasma }\end{array}$ \\
\hline $\begin{array}{l}\text { Association constant, } K \mathrm{a} \\
\quad\left(M^{-1}\right)\end{array}$ & $5 \times 10^{6}$ & $1.3 \times 10^{9}$ & $1.2 \times 10^{9}$ & $?$ & $5 \times 10^{8}$ & $?$ & $?$ & $1 \times 10^{11}$ \\
\hline $\begin{array}{l}\text { Inhibition of renin } \\
\text { enzymatic activity }\end{array}$ & Yes & No & No & Yes & No & Yes & No & Yes \\
\hline Affinity constant, $K \mathrm{i}(n M)$ & ND & & & $0.10-0.18$ & & $0.25-0.40$ & & ND \\
\hline Specificity & $\begin{array}{c}\text { Primate } \\
\text { renin }\end{array}$ & ND & ND & $\begin{array}{c}\text { Primate } \\
\text { renin }\end{array}$ & ND & $\begin{array}{c}\text { Primate } \\
\text { renin }\end{array}$ & ND & $\begin{array}{c}\text { Primate } \\
\text { renin }\end{array}$ \\
\hline \multicolumn{9}{|l|}{ Main potential applications } \\
\hline Immunopurification & Yes & Yes & ND & ND & ND & Yes & No & No \\
\hline $\begin{array}{l}\text { Separation of active and } \\
\text { inactive renin }\end{array}$ & No & No & ND & ND & ND & Yes & No & No \\
\hline Immunohistochemistry & No & Yes & ND & ND & ND & ND & ND & Yes \\
\hline In vivo renin inhibition & No & No & No & Yes & No & Yes & No & Yes \\
\hline $\begin{array}{l}\text { Renin assay in plasma } \\
\text { from normal } \\
\text { volunteers }\end{array}$ & No & No & $\begin{array}{l}\text { Yes } \\
(+4 G 1)\end{array}$ & $\begin{array}{l}\text { Yes } \\
(+4 G 1)\end{array}$ & No & $\begin{array}{l}\text { Yes } \\
(+4 B 11)\end{array}$ & No & No \\
\hline
\end{tabular}

ND, not determined.

Indeed, we did not expect our antibodies to be directed against the active site, for this site is probably buried in a cleft (39). The kinetic results agree with those obtained in the immunometric screening assay, which showed that $4 G 1$ and $4 B 11$ are directed against two topologically different epitopes.

Table IV. Radioimmunometric Detection of Renin (34 ng)

\begin{tabular}{llllll}
\hline \multirow{7}{*}{ First antibody } & \multicolumn{2}{l}{ Second antibody } & & & \\
\cline { 2 - 6 } & $2 \mathrm{D} 12$ & $3 \mathrm{E} 8$ & $4 \mathrm{~B} 11$ & $4 \mathrm{E} 1$ & 4G1 \\
\hline 1A12 & - & - & + & - & + \\
3E8 & - & - & + & + & + \\
4B11 & - & + & - & ND & + \\
4E1 & \pm & + & + & - & + \\
4G1 & - & + & + & + & - \\
\hline
\end{tabular}

The first antibody is coated on the plate. Renin is detected by the binding of $200,000 \mathrm{cpm}$ iodinated second antibody. The signals obtained with the different pairs of antibodies are: + , signal $>100,000$ $\mathrm{cpm} /$ well; \pm , signal $\sim 20,000 \mathrm{cpm} /$ well; - , signal < 10,000 cpm/ well. ND, not determined.

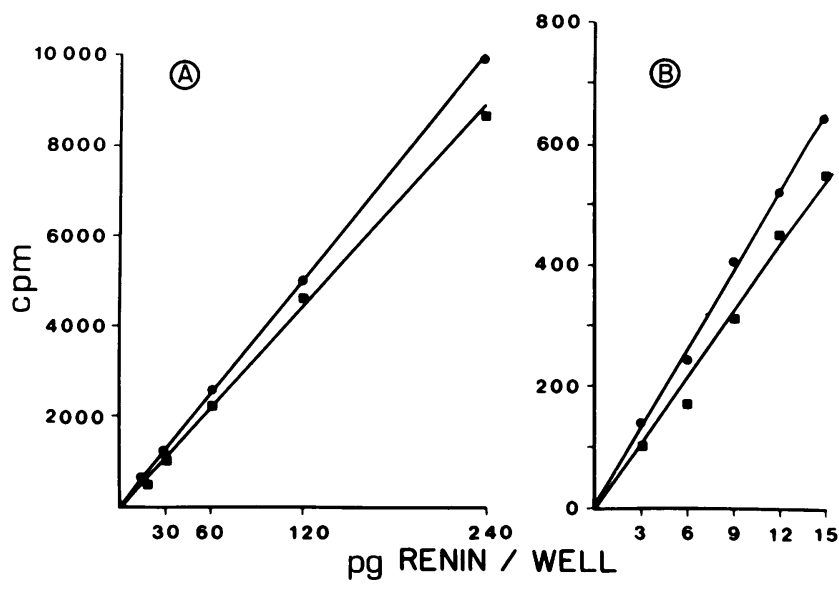

Figure 10. Standard curve for radioimmunometric assay of renin. 3E8 was insolubilized on the plates and 4G1 was the labeled detector. Pure tumoral renin (renin source IV) was used as a standard: $n$, standard curve constructed in $0.1 \mathrm{M}$ phosphate buffer $\mathrm{pH} 7.5 ; \bullet$, standard curve constructed in renin free human plasma. The linearity of the standard curve was observed between 15 and $240 \mathrm{pg}$ of renin $(A)$ and 3-15 pg $(B)$. 
Fig. 5 emphasizes the high species specificity of $4 \mathrm{Gl}$ and 4B11: a 100-fold excess of hog renin and a 1,000-fold excess of mouse renin did not displace the binding to iodinated human renin. In addition, a 1,000-fold excess of two acid proteases related to renin, pepsin, and cathepsin $D(10 \mu \mathrm{g} /$ assay) did not modify the binding. The specificity of the antibodies was also tested for inhibition of enzymatic activity. Results confirm the absence of inhibition of hog, mouse, dog, rabbit, and rat renin. However, 4G1, 4B11, and even F15 (40) also inhibit monkey renin. Immunohistochemistry performed on human and monkey kidneys also shows that $1 \mathrm{~A} 12$ and 2D12 are directed against an epitope that must be similar in these species. The high species specificity of at least three of our antibodies is similar to that reported by Dzau for antihuman renin antibodies (37). On the other hand, this author (41) obtained antibodies directed against canine renin that recognized dog, human, hog, beef, and mouse renin to the same extent. High specificity may be a distinct feature of antibodies raised against human renin, as even polyclonal antibodies obtained in two different laboratories $(4,9)$ also have a very high specificity. Monoclonal antibodies that strongly inhibit renin in the primate are of great biological interest. It has already been demonstrated that polyclonal antibodies decrease the blood pressure of conscious salt-depleted Macacus (7) and marmoset monkeys (8). Preliminary results show that the $4 \mathrm{Gl}$ antibody was also able to decrease the blood pressure of conscious salt-depleted marmosets (unpublished data).

Another goal of this study was to obtain monoclonal antibodies that allow the immunopurification of renin. Antibodies F15, 1A12, and $4 \mathrm{Gl}$ coupled to Sepharose bound active renal renin. The conditions of renin elution depended on the affinity of the antibodies for the active renin molecule. Renin was easily eluted under mild conditions from the low affinity gel, F15, whereas renin elution from high affinity gels $1 \mathrm{~A} 12$ and $4 \mathrm{G} 1$ required the use of $6 \mathrm{M}$ urea. The availability of a set of monoclonal antibodies that have a large range of affinities is very advantageous compared with polyclonal antibodies. R15 renin antiserum was a poor tool in purifying renin by immunoaffinity, as the elution conditions required were too drastic and the recovery was very low $(<20 \%)$. It was used only to prepare renin-free plasma as a source of human angiotensinogen (10). Other authors, using an anti-human renin IgG-Sepharose for immunopurification, obtained a $25 \%$ recovery of renin (42). However, monoclonal antibodies as immunoaffinity ligands provided two interesting applications: one, a large-scale purification of human renin providing in one step an 825-fold renin enrichment from a semipurified material with a 53\% recovery; and two, the separation of active from inactive renin. The separation of active from inactive renin was possible because $4 \mathrm{~B} 11$ and $4 \mathrm{G} 1$ antibodies recognized inactive renin to a lesser extent than they did active renin. Indeed, a 4G1-gel can purify and separate both forms of renin in a single step. This is the case for renin from amniotic liquid, kidney, plasma, and chorionic cell culture. Whatever the renin source, a clear-cut separation is obtained and the inactive renin is retained to a lesser extent on the gel than is active renin. In contrast, polyclonal antibodies $(9,10,42)$ and the monoclonal antibody F15 (40) recognize equally both forms of renin.

The separation of inactive and active renin by the 4G1-gel has important practical applications. Currently, there is no simple method for the simultaneous separation and purification of the two forms of renin. At present the most often used methods of separation of active and inactive renin are affinity chromatography on Sepharose-pepstatin and Affi-gel blue chromatography. These selectively adsorb one form of renin while the other elutes with the bulk of the proteins $(43,44)$. In plasma, inactive renin is difficult to measure without previous purification. The 4G1-gel will allow a simple and rapid extraction of inactive renin from plasma and, hence, the development of an assay for the inactive enzyme.

Renin was localized in the kidney by immunohistochemistry with monoclonal antibodies, as it was with polyclonal antibodies. This result is important for it means that from now on immunohistochemical studies of renin can be carried out with an unlimited source of pure antibodies.

The radioimmunometric assay offers several advantages over the existing direct RIA for renin, which we described for polyclonal antibodies (10): a linear standard curve that allows the detection of renin between 3 and $240 \mathrm{pg}$; no requirement for pure iodinated renin; and enhanced sensitivity (3 pg [i.e., $20 \mathrm{pg} / \mathrm{ml}$ plasma] vs. $25 \mathrm{pg}$ [ $250 \mathrm{pg} / \mathrm{ml}$ plasma]) for the direct RIA.

The immunometric assay is sensitive enough to detect renin in normal subjects, and the evaluation of this new radioimmunometric assay of renin is in progress to discover whether plasma renin can be detected under any physiopathological circumstances and to determine which form(s) of renin is being measured.

In conclusion, one has to ask if monoclonal antibodies are more useful than their polyclonal counterparts. Monoclonal antibodies take longer and cost more to produce. However, the availability of antibodies in a pure form and unlimited scale are ample justification for such an enterprise. The results obtained in immunohistochemistry for the localization of renin are similar with both polyclonal and monoclonal antibodies. Both monoclonal and polyclonal antibodies are expected to evoke the same decrease in blood pressure in salt-depleted monkeys. Properties that are unique to monoclonal antibodies and that are of biological interest are the separation of active and inactive renin from different sources, the qualitative and quantitative purification of the enzyme, and a more sensitive direct assay of human plasma renin. This set of monoclonal antibodies has proved therefore to be a highly valuable new tool in the investigation of the renin-angiotensin system. 


\section{Acknowledgments}

The skillful assistance of Mrs. I. Laboulandine is greatly appreciated. The authors thank Dr. Biozzi for providing the high-responder mice. They express their gratitude to Drs. S. Foote and T. Kotchen for stimulating discussions during the revision of the manuscript.

\section{References}

1. Galen, F. X., C. Devaux, T. Guyenne, J. Menard, and P. Corvol. 1979. Multiple forms of human renin. Purification and characterization. J. Biol. Chem. 254:4848-4855.

2. Yokosawa, H., L. A. Holladay, T. Inagami, E. Haas, and K. Murakami. 1980. Human renal renin. Complete purification and characterization. J. Biol. Chem. 255:3498-3502.

3. Slater, E. E., and H. V. Strout. 1981. Pure human renin. Identification and characterisation of two major molecular weight forms. J. Biol. Chem. 256:8164-8171.

4. Galen, F. X., T. Guyenne, C. Devaux, C. Auzan, P. Corvol, and J. Menard. 1979. Direct radioimmunoassay of human renin. $J$. Clin. Endocrinol. Metab. 48:1041-1043.

5. Camilleri, J. P., V. N. Phat, J. Bariety, P. Corvol, and J. Menard. 1980. Use of a specific antiserum for renin detection in human kidney. J. Histochem. Cytochem. 28:1343-1346.

6. Faraggiana, T., K. E. Gresi, T. Tonako; T. Inagami, and A. Lupo. 1982. Immunohistochemical localization of renin in the human kidney. J. Histochem. Cytochem. 30:459-465.

7. Burton, J., E. E. Slater, P. Corvol, J. Menard, and L. H. Hartley. 1982. Use of antihuman renin antisera to inhibit renin in primates. Clin. Exp. Hypertens. 4:322-324.

8. Michel, J. B., J. Wood, K. Hofbauer, P. Corvol, and J. Menard. 1984. Blood pressure effects of renin inhibition by human renin antiserum in normotensive marmosets. Am. J. Physiol. 246:F309F316.

9. Yokosawa, H., N. Yokosawa, and T. Inagami. 1980. Specific antibody to human renal renin and its cross reactivity with inactive human plasma renin. Proc. Soc. Exp. Biol. Med. 164:466-470.

10. Guyenne, T. T., F. X. Galen, C. Devaux, P. Corvol, and J. Menard. 1980. Direct radioimmunoassay of human renin. Comparison with renin activity in plasma and amniotic fluid. Hypertension (Dallas). 2:465-470.

11. Leckie, B. J. 1981. Inactive renin: an attempt at a perspective. Clin. Sci. 60:119-130.

12. Simon, D., F. X. Galen, C. Devaux, F. Soubrier, B. Pau, J. Menard, and P. Corvol. 1981. Monoclonal antibody against human renin. J. Clin. Endocrinol. Metab. 53:453-455.

13. Murakami, K., and T. Inagami. 1975. Isolation of stable renin from hog kidney. Biochem. Biophys. Res. Commun. 62:757-763.

14. Haas, E., H. Goldblatt, E. C. Gipson, and L. V. Lewis. 1966. Extraction, purification and assay of human renin free of angiotensinase. Circ. Res. 19:739-749.

15. Atlas, S. A., J. E. Sealey, T. E. Hesson, A. P. Kaplan, J. Menard, P. Corvol, and J. H. Laragh. 1982. Biochemical similarity of partially purified inactive renin from human plasma and kidney. Hypertension (Dallas). 4(Suppl. II):86-95.

16. Acker, G. M., F. X. Galen, C. Devaux, S. Foote, E. Papernik, A. Pesty, J. Menard, and P. Corvol. 1982. Human chorionic cells in primary culture: a model for renin biosynthesis. J. Clin. Endocrinol. Metab. 55:902-909.
17. Boumsell, L., and A. Bernard. 1980. High efficiency of Biozzi's high responder mouse strain in the generation of antibody secreting hybridomas. J. Immunol. Methods. 38:225-229.

18. Luben, R., and M. Mohler. 1980. In vitro immunization as an adjunct to the production of hybridomas producing antibodies against the lymphokine osteoclast activating factor. Mol. Immunol. 17:635639.

19. Di Pauli, R., and W. C. Raschke. 1978. In Current Topics in Microbiology and Immunology. Vol. 81. F. Melchers, M. Potte, and N. L. Warner, editors. Springer-Verlag, Berlin. 37-39.

20. Ey, P. L., S. J. Prowse, and C. R. Jenkin. 1978. Isolation of pure IgG1, IgG2a and IgG2b immunoglobulins from mouse serum using protein A-sepharose. Immunochemistry. 15:429-436.

21. Menard, J., and K. Catt. 1972. Measurement of renin activity, concentration and substrate in rat plasma by radioimmunoassay of angiotensin I. Endocrinology. 90:422-430.

22. Scatchard, G. 1949. The attractions of proteins for small molecules. Ann. NY Acad. Sci. 51:660-672.

23. Dixon, M., and C. Webb. 1964. Enzymes. Longman Group Ltd., Harlow, England. 328.

24. Cohen, S., J. M. Taylor, K. Murakami, A. M. Michelakis, and T. Inagami. 1972. Isolation and characterization of renin-like enzymes from mouse submaxillary glands. Biochemistry. 11:4286-4293.

25. Corvol, P., C. Devaux, T. Ito, P. Sicard, J. Ducloux, and J. Menard. 1977. Large scale purification of hog renin. Physicochemical characterization. Circ. Res. 41:616-622.

26. Barrett, A. J. 1970. Cathepsin D purification of isoenzymes from human and chicken liver. Biochem. J. 117:601-607.

27. March, S. C., I. Parikh, and P. Cuatrecasas. 1974. A simplified method for cyanogen bromide activation of agarose for affinity chromatography. Anal. Biochem. 60:149-152.

28. Soubrier, F., C. Devaux, F. X. Galen, S. L. Skinner, M. Aurell, J. Genest, J. Menard, and P. Corvol. 1982. Biochemical and immunological characterization of ectopic tumoral renin. J. Clin. Endocrinol. Metab. 54:139-144.

29. Lowry, O. H., N. J. Rosebrough, A. L. Farr, and R. J. Randall. 1951. Protein measurement with Folin phenol reagent. J. Biol. Chem. 193:265-275.

30. Sternberger, L. A., P. H. Hardy, J. J. Cuculis, and H. G. Meyer. 1970. The unlabeled antibody enzyme method of immunohistochemistry. J. Histochem. Cytochem. 18:315-333.

31. Greenwood, F. C., W. M. Hunter, and J. S. Glover. 1963. The preparation of I-131 labeled human growth hormone of high specific radioactivity. Biochem. J. 89:114-118.

32. Phat, V. N., J. P. Camilleri, J. Bariety, M. Galtier, E. Baviera, P. Corvol, and J. Menard. 1981. Immunohistochemical characterization of renin-containing cells in the human juxtaglomerular apparatus during embryonal and fetal development. Lab. Invest. 45:387-390.

33. Amat, D., J. P. Camilleri, N. V. Phat, J. Bariety, P. Corvol, and J. Menard. 1981. Renin localization in segmental renal hypoplasia. Virchows Arch. ABT. A. Pathol. Anat. 390:193-204.

34. Domingo, M. T., J. M. Bastide, C. Clavies, P. Gros, G. Hennen, C. Larue, F. Paolucci, B. Pau, and G. Pirens. 1983. Selection and characterization of monoclonal antibodies directed against human chorionic gonadotropin. In Protides of Biological Fluids. H. Peeters, editor. Pergamon Press. 31:1035-1038.

35. Mumby, M. C., T. J. Martins, M. L. Chang, and J. A. Beavo 1982. Identification of CGMP-stimulated cyclic nucleotide phosphodi- 
esterase in lung tissue with monoclonal antibodies. J. Biol. Chem. 257:13283-13290.

36. Tanaka, S., S. Hu, T. S. Wang, and D. Korn. 1982. Preparation and preliminary characterization of monoclonal antibodies against human DNA polymerase alpha. J. Biol. Chem. 257:8386-8390.

37. Dzau, V. J., D. Devine, M. Mudgett-Hunter, R. I. Kopelman, A. C. Barger, and E. Haber. 1983. Antibodies as specific renin inhibitors: studies with polyclonal and monoclonal antibodies and FAB fragments. Clin. Exp. Hypertension. 5:1207-1220.

38. Henderson, P. J. F. 1972. A linear equation that describes the steady state kinetics of enzymes and subcellular particles interacting tightly bound inhibitors. Biochem. J. 127:321-333.

39. Blundell, T., B. L. Sibanda, and L. Pearl. 1983. Threedimensional structure, specificity and catalytic mechanism of renin. Nature (Lond.). 304:273-275.
40. Pau, B., D. Simon, F. X. Galen, C. Devaux, F. Soubrier, J. Menard, and P. Corvol. 1981. A monoclonal antibody for immunopurification of human renin. Clin. Sci. 61:239s-240s.

41. Dzau, V., M. Mudgett-Hunter, G. Kapler, and E. Haber. 1981. Monoclonal antibodies binding renal renin. Hypertension (Dallas). 3(Suppl. II):4-8.

42. Inagami, T., H. Okamoto, K. S. Ohtsuki, K. Shimamoto, J. Chao, and H. S. Margolius. 1982. Human plasma inactive renin: purification and activation by proteases. J. Clin. Endocrinol. Metab. 55:619-627.

43. Atlas, S. A., J. E. Sealey, B. Dharmgrongartama, T. E. Hesson, and H. Laragh. 1981. Detection and isolation of inactive, large molecular weight renin in human kidney and plasma. Hypertension (Dallas). 3(Suppl. I):30-40.

44. Thang, J. J., M. Kisaragi, H. Okamoto, and T. Inagami. 1981. Isolation of inactive renin from human kidney and plasma. Hypertension (Dallas). 3:509-515. 